\title{
Stemphylium Leaf Spot of Parsley in California Caused by Stemphylium vesicarium
}

Steven T. Koike, University of California Cooperative Extension, Salinas 93901; Nichole O’Neill and Julie Wolf, United States Department of Agriculture-Agricultural Research Service (USDA-ARS), Systematic Mycology and Microbiology, and Peter Van Berkum, USDA-ARS, Soybean Genomics and Improvement Laboratory, Beltsville, MD 20705; and Oleg Daugovish, University of California Cooperative Extension, Ventura 93003

\begin{abstract}
Koike, S. T., O’Neill, N., Wolf, J., Van Berkum, P., and Daugovish, O. 2013. Stemphylium leaf spot of parsley in California caused by Stemphylium vesicarium. Plant Dis. 97:315-322.

From 2009 through 2011, a previously undescribed disease occurred on commercial parsley in coastal (Ventura County) California. Symptoms of the disease consisted of circular to oval, tan to brown leaf spots and resulted in loss of crop quality and, hence, reduced yields. A fungus was consistently isolated from symptomatic parsley. Morphological and molecular data identified the fungus as Stemphylium vesicarium. When inoculated onto parsley leaves, the isolates caused symptoms that were identical to those seen in the field; the same fungus was recovered from test plants, thus completing Koch's postulates. Additional inoculation experiments demonstrated that 10 of 11 tested flat leaf and curly parsley cultivars were susceptible. The parsley isolates also caused small leaf spots on other Apiaceae family plants (car-

rot and celery) but not on leek, onion, spinach, and tomato. Isolates caused brown lesions to form when inoculated onto pear fruit but only when the fruit tissue was wounded. Using a freeze-blotter seedborne pathogen assay, parsley seed was found to have a low incidence $(0.25 \%)$ of $S$. vesicarium. When inoculated onto parsley leaves, three of four isolates from seed caused the same leaf spot disease. This is the first documentation of a foliar parsley disease caused by $S$. vesicarium. The occurrence of $S$. vesicarium on parsley seed indicates that infested seed may be one source of initial inoculum. Based on the negative results in the host range experiments, it appears that this parsley pathogen differs from the $S$. vesicarium that causes disease on leek, garlic, onion, and pear fruit.
\end{abstract}

Parsley (Petroselinum crispum) is a familiar leafy plant in the Apiaceae family that is grown as both a fresh market commodity for use as a vegetable, herb, and garnish and as a dehydrated product for various culinary uses. California is the number one producer of parsley in the United States, with over 1,043 ha grown in 2010 (6), representing approximately half of the country's parsley (50). Two coastal counties, Monterey and Ventura, grow $49 \%$ of California's parsley; in 2010, these counties accounted for 509 ha of parsley that was valued at $\$ 13.5$ million (6). The California parsley crop consists of both curly and flat leaf cultivars. Parsley crops are direct seeded, grown to harvestable size, hand harvested or mechanically mowed, then allowed to regrow for additional harvests. This harvest-and-regrowth practice can be done up to three times.

Parsley production in California involves high seeding rates that result in dense plant populations and thick canopies. This planting practice, combined with the fact that all parsley crops are irrigated with overhead sprinklers, creates conditions in which foliar diseases can be problematic. In California, the most damaging foliar disease has historically been Septoria late blight caused by Septoria petroselini (23). Septoria late blight has been managed by using pathogen-free seed and by applying foliar fungicides $(24,32)$. Other, less important foliar concerns in California are powdery mildew caused by Erysiphe orontii (26), bacterial leaf spot caused by two pathovars of Pseudomonas syringae (5), and a virus disease caused by Apium virus $Y(25,49)$.

From 2009 through 2011, unfamiliar foliar symptoms were observed on commercial flat leaf parsley grown for the fresh market in Ventura County, CA. Both conventional and organic parsley

Corresponding author: S. T. Koike, E-mail: stkoike@ucdavis.edu

Accepted for publication 4 September 2012.

http://dx.doi.org/10.1094/PDIS-06-12-0611-RE

(C) 2013 The American Phytopathological Society plantings were affected. Initial symptoms consisted of leaf spots that were 2 to $3 \mathrm{~mm}$ in diameter, circular to oval in shape, and chlorotic. As disease progressed, the spots enlarged to 5 to $8 \mathrm{~mm}$, retained a circular to oval shape, and turned tan to light brown in color, with chlorotic borders. In some cases, leaf spots exhibited a ringspot or target appearance due to alternating lighter- and darkercolored tissue (Fig. 1). When the disease was severe, the leaf spots coalesced and the leaves became prematurely chlorotic and senescent, eventually drying up and resulting in leaf dieback (Fig. 1). Leaf petioles were also diseased and had narrow, elongated, brown lesions. Spots occurred mostly but not exclusively on older foliage. When the parsley was harvested, the remaining lower, older leaves still attached to the plants often exhibited the most severe symptoms; the disease also reappeared on the subsequent regrowth following a harvest. Overall maximum disease incidence was estimated at $30 \%$. Sparse fungal growth was sometimes observed on adaxial leaf spot surfaces but obvious fungal fruiting bodies were absent from the spots. Because of the high quality standards for this leafy commodity, the problem resulted in yield loss because diseased sections in some fields were not harvested. The purposes of this study were to determine the cause of this leaf spot problem, characterize the pathogen, and investigate possible sources of primary inoculum.

\section{Materials and Methods}

Isolation of the causal agent. Symptomatic leaves were surface sterilized by soaking leaf pieces in $1 \%$ bleach $(0.525 \%$ sodium hypochlorite) solutions for $3 \mathrm{~min}$. Small (3-by-3-mm) sections of tissue were aseptically excised from leaf spot margins and placed into petri plates containing corn meal agar (CMA; Difco Laboratories) that was acidified ( $25 \%$ lactic acid at $2 \mathrm{ml} / \mathrm{liter})$. Plates were incubated in light from a combination of cool white and Vita-Lite fluorescent tubes on a cycle of $12 \mathrm{~h}$ of light and $12 \mathrm{~h}$ of darkness at $22^{\circ} \mathrm{C}$ and examined after 5 to 7 days for fungal growth. Singlespored cultures of isolated fungi were subsequently stored on potato dextrose agar (PDA; Difco Laboratories) slants at $5^{\circ} \mathrm{C}$. To test for bacterial pathogens, small pieces of the surface-sterilized leaf 
spots were aseptically excised from leaf spot margins and macerated in $40 \mu \mathrm{l}$ of sterile distilled water (SDW). The resulting suspensions were streaked onto sucrose peptone agar plates and incubated at $22^{\circ} \mathrm{C}$. After 3 to 5 days, these plates were examined for bacterial growth. Nonsterilized leaf spot pieces were also excised and placed in a drop of water on glass slides to examine for bacterial streaming with a compound microscope.

Morphological characterization of Stemphylium isolates. Seven isolates taken from diseased plants were single spored and grown on half-strength V8 agar medium incubated in light on a cycle of $12 \mathrm{~h}$ of light and $12 \mathrm{~h}$ of darkness at $22^{\circ} \mathrm{C}$. Morphological examination was conducted for all isolates after 7 days and measurements taken for two representative isolates after 14 days. At least 50 conidia and 20 conidiophores were measured per isolate. Photomicrographs were taken using a Zeiss Axioplan II Imaging Microscope, Axiocam digital camera, and Axiovision imaging software (Carl Zeiss Microimaging Inc.). Semi-permanent mounts were prepared in Shear's solution $(300 \mathrm{ml}$ of $2 \%$ aqueous potassium acetate, $120 \mathrm{ml}$ of glycerin, and $120 \mathrm{ml}$ of $95 \%$ ethyl alcohol).

Molecular characterization of Stemphylium isolates. For extracting DNA, isolates were grown in shake cultures at $22^{\circ} \mathrm{C}$ for 14 days in $100 \mathrm{ml}$ of potato dextrose broth $(24 \mathrm{~g} /$ liter $)$. The resulting mycelial mats were collected by filtration and then lyophilized. The lyophilized mycelium (50 mg/isolate) was ground in liquid nitrogen using a sterile micropestle. DNA was extracted using the Qiagen DNeasy Plant Mini Kit according to the manufacturer's instructions. Samples were stored at $-20^{\circ} \mathrm{C}$.

A partial section of the $g p d$ gene was amplified by using the primers $g p d$ f5'-GCA CCG ACC ACA AAA ATC-3' and gpd r5'-
GGG CCG TCA ACG ACC TTC-3' designed with the software package Oligo Primer Analysis Software (version 6.65; Molecular Biology Insights, Inc.) using sequences of Stemphylium spp. deposited in GenBank. The polymerase chain reaction (PCR) was optimized using a commercially available kit (Invitrogen). The reaction conditions that were used were $10 \mu \mathrm{l}$ of $5 \times$ buffer $\mathrm{C}(60$ $\mathrm{mM}$ Tris-HCL, $15 \mathrm{mM}\left(\mathrm{NH}_{4}\right)_{2} \mathrm{SO}_{4}$, and $2.5 \mathrm{mM} \mathrm{MgCl} \mathrm{Mg}_{2}$ at a final $\mathrm{pH}$ of 8.5$) ; 1.25 \mu \mathrm{l}$ each $(10 \mathrm{mM})$ of dATP, dCTP, dGTP, and dTTP; $5 \mu$ leach $(10 \mathrm{pmol} / \mu \mathrm{l})$ of the primers $g p d \mathrm{f}$ and $g p d \mathrm{r}$ (gpd region); $2 \mu \mathrm{l}$ of Perkin Elmer Taq polymerase; and $22 \mu \mathrm{l}$ of sterile water. Amplifications were performed with an ERICOMP Delta Cycler II system using the following program parameters: 35 cycles of $94^{\circ} \mathrm{C}$ for $30 \mathrm{~s}, 57^{\circ} \mathrm{C}$ for $1 \mathrm{~min}$, and $72^{\circ} \mathrm{C}$ for $1.5 \mathrm{~min}$; and a final extension at $72^{\circ} \mathrm{C}$ for $3 \mathrm{~min}$. The presence of PCR products was verified by UV illumination of horizontal agarose $(0.7 \%$ [wt/vol]) gels after electrophoresis in the presence of ethidium bromide $(\mathrm{EtBr})(0.08 \mu \mathrm{g} / \mathrm{ml})$.

The presence of a single PCR product of the expected molecular size using each primer pair with each of the different templates was verified before sequence analysis. Each PCR product was then purified to remove the PCR primers by using the Ampure PCR purification system (Agincourt Bioscience Corporation). The purified PCR products were used in each of two forward and two reverse sequence reactions with the nested sequence primers $g p d$-ef 5'-CGG CTT CGG TCG CAT G-3', gpd-if 5'-CAC GGC CAG TTC AAG-3', gpd-er 5'-GCC AAG CAG TTG GTT GTG-3', and gpd-intU 5'-CGC GGC GGT TGG AGG ACA TTT-3'. An Applied Biosystems 3130 DNA Analyzer in combination with a Dye Deoxy Terminator Cycle Sequencing Kit (Applied Biosystems) was used

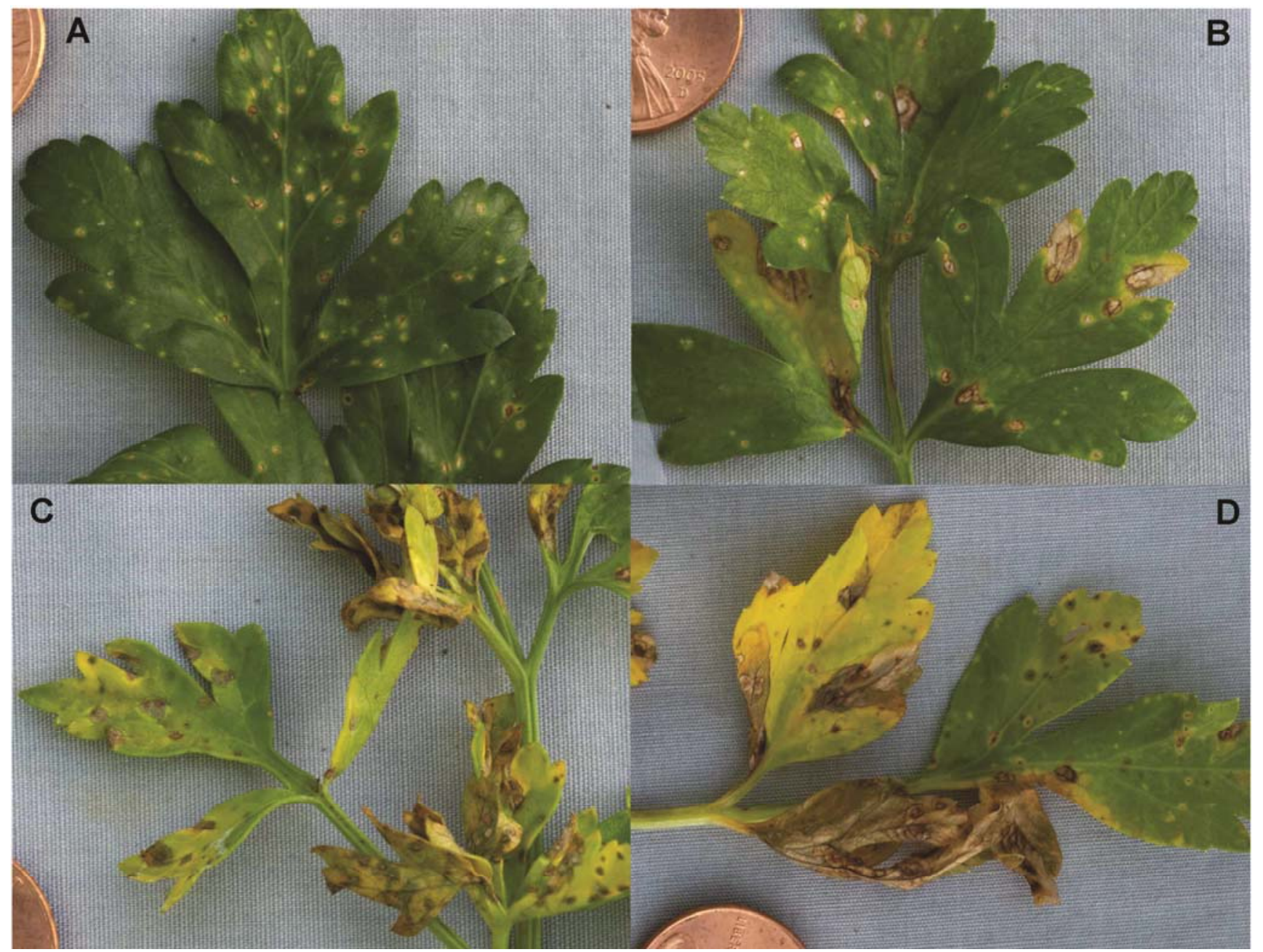

Fig. 1. Symptoms of Stemphylium leaf spot of parsley caused by Stemphylium vesicarium. A, Initial symptoms are small, circular, chlorotic spots. B, As disease develops, the spots enlarge, turn tan to brown, and have chlorotic borders. C and D, Spots may exhibit concentric rings and result in necrosis and early senescence of the leaf. 
for sequencing the purified PCR products as described previously (51). Sequences were aligned with GeneDoc (version 2.6.001; K. B. Nicholas and H. B. Nicholas; http://www.nrbsc.org/gfx/gene doc/index.html). Accuracy of the alignments was checked and adjustments made using GeneDoc. A neighbor-joining tree of Jukes-Cantor distances of the partial glyceraldehyde-3-phosphate dehydrogenase DNA sequences was generated with the Molecular Evolutionary Genetics Analysis software, version 4.0 (48), with the sequence of Alternaria alternata (GenBank accession AF 081400) as an outgroup. Confidence values for the branches were obtained by bootstrap analysis using 2,000 permutations of the dataset. The sequences for gpd were deposited in GenBank under accession number JX139753.

Pathogenicity of Stemphylium vesicarium isolates to parsley. To document pathogenicity to parsley, six representative isolates (STM 09-12B1, 09-13B1, 09-14B1, 09-15B1, 09-17B1, and 0918B2) of Stemphylium vesicarium recovered from diseased parsley were grown for 4 weeks on V8 juice agar medium under a cycle of $12 \mathrm{~h}$ of light and $12 \mathrm{~h}$ of darkness at $22^{\circ} \mathrm{C}$. Conidial suspensions $\left(1.5 \times 10^{5}\right.$ conidia/ml $)$ were prepared, Tween 20 was added ( 1 drop per $500 \mathrm{ml}$ ), and the mixture was sprayed with a hand-held mister until runoff onto 24 parsley ('Italian Flat Leaf') plants, growing in six-pack containers, each having 6 to 10 true leaves. Plants were subsequently placed in clear plastic bags for $48 \mathrm{~h}$, removed from bags, and then incubated in a greenhouse $\left(20\right.$ to $\left.24^{\circ} \mathrm{C}\right)$. Control plants were sprayed with SDW plus Tween 20 and handled in the same way. When symptoms developed, isolations were conducted as described above. The inoculation experiment was conducted two times.

To evaluate the susceptibility of various parsley cultivars to the pathogen, separate conidial suspensions of four isolates (STM 0912B1, 09-13B1, 09-14B1, and 09-15B1) were prepared as described above and sprayed onto 12 plants each of five flat and six curly leaf parsley cultivars, growing in six-pack containers, each having 6 to 10 true leaves. An SDW plus Tween 20 control was included for each cultivar. Plants were incubated as described above. Results were evaluated at 24 days post inoculation (dpi) when 10 symptomatic leaves were randomly collected per cultivar. For all leaflets, spots were measured and categorized as being either smaller or larger than $5 \mathrm{~mm}$ in diameter. Isolations were conducted from these collected leaves. The inoculation experiment was conducted two times.

Pathogenicity of $S$. vesicarium parsley isolates to other plants. Host range was investigated with the same four isolates used in the parsley cultivar inoculations. Separate conidial suspensions of these four isolates were prepared as before and sprayed onto 12 plants each of following plants: carrot (Daucus carota subsp. sativus 'Scarlet Nantes' and 'Tendersweet'), celery (Apium graveolens 'Conquistador'), leek (Allium porrum 'Lancelot'), onion (A. cepa, 'California Red'), spinach (Spinacia oleracea 'Bolero' and 'Lazio'), and tomato (Solanum lycopersicum 'Champagne'). Prior to inoculating the leek and onion plants, leaves were lightly rubbed with cheesecloth so as to partially remove the waxy cuticle (43). Parsley ('Dark Green Italian') plants were inoculated as a positive control. An SDW plus Tween 20 control was included for each cultivar. Plants were incubated as described above. Plants were evaluated at $24 \mathrm{dpi}$ for presence or absence of leaf spots, and the experiment was completed two times.

In addition, organically grown pear (Pyrus communis 'Bartlett') fruit that were never treated with fungicides were inoculated with the same spore suspensions used on plants. Fruit were placed on wire racks inside plastic crisper boxes and water was added to the bottom of the boxes. Two unripe green and two ripe yellow pear fruit were used for each inoculation. One drop of inoculum was placed on each of six unwounded and six wounded spots on each fruit. Wounding was done by pushing a sterilized dissecting needle approximately $2 \mathrm{~mm}$ deep into the fruit. The boxes were closed with their lids and incubated at $22^{\circ} \mathrm{C}$ in the dark for $48 \mathrm{~h}$ (22). After $48 \mathrm{~h}$, the pear fruit were placed in a dry, open crisper and maintained at $22^{\circ} \mathrm{C}$. An SDW plus Tween 20 control was used on both unwounded and wounded green and yellow pear fruit. Fruit were examined for up to 10 days for lesion development. The experiment was completed twice.

Assaying for seedborne inoculum. Because Stemphylium pathogens on crops such as onion $(1,35)$, radish (Raphanus sativus) (4), and spinach (19) are known to be seedborne, parsley seed was tested for Stemphylium vesicarium using a freeze-blotter assay $(10,11)$. The grower who first reported this disease provided seed ('Italian Flat Leaf') from the original seed lot used to grow the affected crop. For each experiment, four replications of 100 seeds each were placed in a stainless steel tea strainer that was agitated for $1 \mathrm{~min}$ in a $1.2 \%$ bleach $(0.525 \%$ sodium hypochlorite $)$ solution. Seed were triple-rinsed in SDW, placed on sterile paper towels in a laminar flow hood to dry, and finally arranged singly onto sterilized steel-blue germination blotter paper (Anchor Paper Company) lining plastic incubation boxes. The boxes were 10-by-10$\mathrm{cm}$, clear acrylic containers with tight-fitting, clear lids (Hoffman Manufacturing, Inc.). The blotter paper was moistened with approximately $15 \mathrm{ml}$ of SDW.

The parsley seed were arranged on the blotters in six rows of 6 seeds/box (maximum of 36 seeds/box) using sterilized forceps; therefore, three boxes were used for each replication. The lid was then tightly secured on each box. The boxes were incubated in the dark for $24 \mathrm{~h}$ while the seed imbibed water, placed in a freezer $\left(-20^{\circ} \mathrm{C}\right)$ for $24 \mathrm{~h}$ to freeze-kill the imbibed seed, and then placed under lights (near-UV light and cool white fluorescent light) on a cycle of $12 \mathrm{~h}$ of light and $12 \mathrm{~h}$ of darkness at $22^{\circ} \mathrm{C}$. If not subject to freezing, imbibed seed will germinate, making it difficult to observe fungal growth on the seed coats. Seed were examined for Stemphylium spp. and other dematiaceous fungal species with a dissecting stereomicroscope at 5, 10, and 14 days after being removed from the freezer. Suspected Stemphylium fungi were isolated and single-spored cultures of these isolates were subsequently stored on PDA slants at $5^{\circ} \mathrm{C}$. This experiment was completed four times.

Pathogenicity of seedborne isolates to parsley. To determine whether Stemphylium isolates obtained from parsley seed were pathogenic to parsley, isolates were grown for 4 weeks on V8 juice agar medium under a cycle of $12 \mathrm{~h}$ of light and $12 \mathrm{~h}$ of darkness at $22^{\circ} \mathrm{C}$. Conidial suspensions $\left(1 \times 10^{5}\right.$ conidia/ml $)$ were prepared and sprayed onto 12 parsley ('Dark Green Italian') plants as described above. Inoculated plants were incubated as per the previous pathogenicity tests. Control plants were sprayed with SDW plus Tween 20 and handled in the same way. Plants were evaluated at 24 dpi to determine presence or absence of leaf spots. If symptoms developed, isolations were conducted and resulting Stemphylium isolates identified to species. This inoculation experiment was conducted three times.

\section{Results}

Isolation of the causal agent. Cut leaf spot edges lacked bacterial streaming when examined with a compound microscope, and no bacteria were recovered from the leaf section suspensions streaked onto sucrose peptone agar. Leaf spot surfaces generally did not have visible fungal growth and no distinct fruiting bodies were present. However, a fungus was consistently isolated from tissues removed from the margins of leaf spots and plated onto acidified CMA. Colonies on acidified CMA were dark green to gray in color, with whitish aerial mycelium, and sporulated sparsely. To obtain greater sporulation, isolates were transferred to V8 juice agar medium and incubated under lights for all experiments. Monoconidial cultures of representative isolates were obtained from these V8 juice agar cultures and stored on PDA slants at $5^{\circ} \mathrm{C}$. No other fungi were isolated from the leaf spots.

Morphological and molecular characterization of Stemphylium isolates. The seven isolates of Stemphylium recovered from symptomatic parsley leaves were morphologically similar. Dictyoconidia were brown colored, broadly ellipsoidal to oblong, and borne singly (Fig. 2). Conidia often had three main transverse septa, at which points there were conspicuous constrictions. Outer 
conidial walls had verrucose ornamentation. Conidia dimensions were mostly 22 to 28 (mean of 26) $\mu \mathrm{m}$ long and 13 to 16 (mean of 15) $\mu \mathrm{m}$ wide; the mean length/width ratio was 1.8 (Table 1). Conidiophores were mostly unbranched, 6 to $8 \mu \mathrm{m}$ wide, with distinctly swollen apical cells ( 8 to $11 \mu \mathrm{m}$ wide) having darkly pigmented bands (Table 1). These morphological features fit the descriptions for $S$. vesicarium (46). A Pleospora sp. teleomorph stage was not observed on diseased parsley collected from the field and did not develop on inoculated plants or in culture. From sequence analysis of the partial gpd gene, the parsley isolates were identified within the genus Stemphylium. The partial gpd sequences of the parsley isolates $S$. vesicarium (EGS 37-067), S. herbarum (EGS 30-181.1 and EGS 36-138.2), S. alfalfae (EGS 36-088, EGS 40-038, and EGS 39-127), and a Stemphylium sp. (EGS 44-149) were identical (Fig. 3). Based on the morphological and molecular data, the parsley isolates were identified as Stemphylium vesicarium (Wallr.) E. G. Simmons (7,45,46).

Pathogenicity of $S$. vesicarium to parsley. For all six isolates, leaf spots developed on inoculated parsley ('Italian Flat Leaf') plants between 20 and 24 dpi and closely resembled symptoms observed on the originally infected field plants. Fungal fruiting bodies and structures did not form on leaf spot surfaces. Stemphylium fungi morphologically similar to the original isolates were consistently isolated from the leaf spots and, after morphological and molecular characterization, confirmed to be the same as the original isolates. None of the control plants treated with SDW plus Tween 20 developed symptoms. Results from the two experiments were the same.

Susceptibility of parsley cultivars. Leaf spots developed on all five flat leaf parsley cultivars tested for susceptibility to $S$. vesicarium (Table 2) and the pathogen was reisolated from symptomatic tissue. Slight differences in disease severity were observed among the flat leaf cultivars. 'Dark Green Italian' and 'Italian Flat Leaf' consistently had larger lesions ( $\geq 5 \mathrm{~mm}$ in diameter) than the other cultivars in both the first and second experiments (Table 2). For 'Forest Green', 'Rialto', and 'Titan', the leaf spots were smaller
( $<5 \mathrm{~mm}$ in diameter) for the second experiment that was conducted during the warmer, drier month of June (Table 2). None of the control plants treated with SDW developed symptoms.

For curly leaf parsley, five of the six cultivars ('Dark Moss Curled', 'Evergreen', 'Jane', 'Krausa', and 'Moss Curled') developed leaf spots that were consistently less than $5 \mathrm{~mm}$ in diameter (Table 2). Curly leaf 'Triple Curled' generally did not develop leaf spots following inoculations, except with isolates STM 09-13B1 (second inoculation only) and STM 09-14B1 (first inoculation only) (Table 2). The pathogen was consistently reisolated from leaf spots on all curly leaf parsley. None of the control plants treated with SDW developed symptoms.

Pathogenicity of $S$. vesicarium isolates from parsley to other plants. After 24 days, positive control flat leaf parsley ('Dark Green Italian') developed typical leaf spots resembling symptoms seen in the field. Celery and both carrot cultivars developed small ( $<5 \mathrm{~mm}$ in diameter) leaf spots that were circular to oval, tan to light brown in color, and sometimes exhibited a ring spot appearance (Table 2). The $S$. vesicarium pathogen was consistently reisolated from parsley, celery, and two carrot cultivars. Leaf spots did not develop on inoculated leek, onion, spinach, or tomato (Table 2). For inoculated pear fruit, circular, dark-brown lesions developed at wounded sites on both green immature and yellow mature fruit. $S$. vesicarium was reisolated from these fruit lesions. No lesions formed at the unwounded sites on green immature or yellow mature fruit. None of the control plants or fruit treated with SDW plus Tween 20 developed symptoms. Results from the two experiments were the same (Table 2).

Assaying for seedborne inoculum. Parsley seed tested with a freeze-blotter assay were evaluated for dematiaceous fungi at 5, 10, and 14 days after removal from the freezer. The recorded numbers of seed supporting growth of dematiaceous fungi did not increase from 10 to 14 days; however, in some cases, by day 14, white, aerial, floccose fungal growth obscured the seed. Therefore, numbers recorded at day 10 were considered as the final counts (Table 3 ). With the seed assay repeated four times (400 seeds per experi-

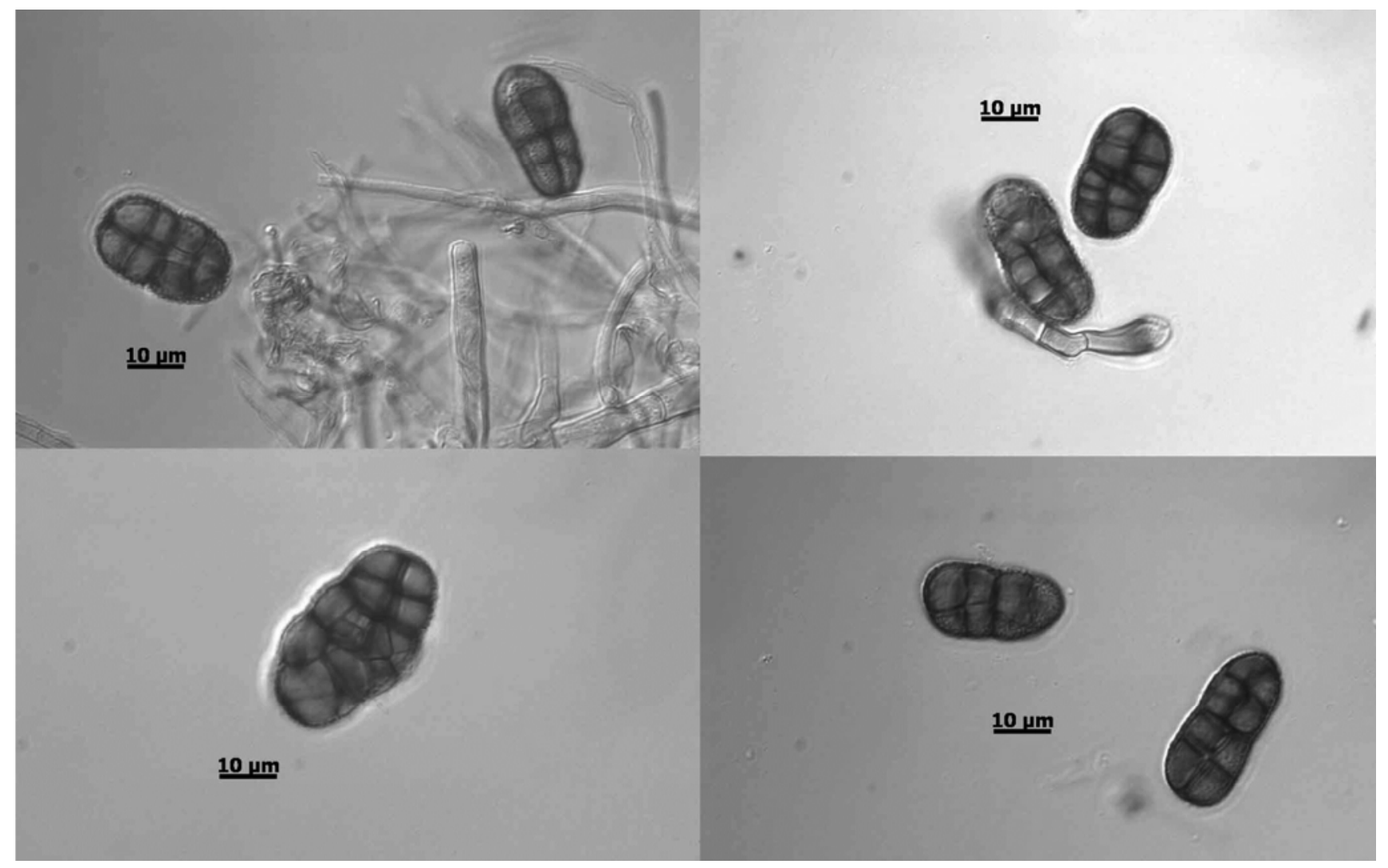

Fig. 2. Conidia of Stemphylium vesicarium isolated from parsley and grown on V8 agar medium under lights $(\times 400)$. 
ment), the mean percentage of seed supporting growth of Stemphylium was $0.25 \%$. A Ulocladium fungus was present on $0.63 \%$ of the seed, while an Alternaria sp. having small conidia borne in long chains appeared at $2.9 \%$. The Stemphylium isolates were morphologically similar to $S$. vesciarium isolated from leaf spots and, therefore, were single spored and stored in PDA slants.

Pathogenicity of seedborne isolates to parsley. Four $S$. vesicarium isolates were recovered from the parsley seed assays (Table 3), stored as single-spored cultures, and used to inoculate parsley plants. Three of the isolates caused leaf spots 20 to 24 dpi when inoculated onto parsley ('Dark Green Italian'); the fourth isolate failed to cause disease after repeated inoculations. All Stemphylium fungi reisolated from leaf spots of inoculated plants were morphologically similar to $S$. vesicarium from field plantings. None of the control plants treated with SDW plus Tween 20 developed symptoms. Results from the three inoculation experiments were the same.

\section{Discussion}

This is the first documentation of Stemphylium leaf spot of parsley caused by $S$. vesicarium in California and the first characterization of a Stemphylium foliar pathogen on this crop (15). Morphological and molecular data supported the identification of the parsley isolates as $S$. vesicarium, which belongs to the $S$. vesicarium species group (46). Species within this Stemphylium clade are indistinguishable based on DNA sequences using different loci (20) and include $S$. vesicarium, $S$. herbarum, and $S$. alfalfa. In multiple inoculation experiments, the flat leaf parsley cultivars were affected more severely than curly leaf types. The pathogen does not appear to be extremely aggressive, and the disease developed slowly under experimental conditions. The ability of $S$. vesicarium to infect parsley appears sensitive to environmental conditions, because experiments conducted during warmer, drier ambient conditions (in June) resulted in less severe symptoms and, in some cases, lack of leaf spot development.

To our knowledge, the only other report of a Stemphylium foliar pathogen was a 1962 abstract describing a Stemphylium leaf spot occurring on parsley in New Jersey (30); however, the pathogen species was not identified or characterized. The Lewis report (30) indicated that, upon inoculating multiple crops in the Apiaceae family, the Stemphylium isolate from parsley infected parsley, celery, celeriac, fennel, dill, and parsnip; however, carrot, caraway, and anise did not develop disease. In our host range experiments, both carrot and celery were susceptible to $S$. vesicarium isolates from parsley. Given the lack of details in the 1962 report, it is not possible to draw conclusions regarding any possible relatedness of the California and New Jersey outbreaks. In other reports concerning Stemphylium spp., S. botryosum has been associated with pars- ley seed $(16,36)$ and with a parsley seedling disease that involved a number of fungi $(34,37)$.

$S$. vesicarium is reported on a number of other agronomic crops and causes purple leaf blotch or leaf blight of garlic (A. sativum), leek (A. ampeloprasum), and onion (A. cepa) $(39,40,43,47)$; Stemphylium leaf spot or purple spot of asparagus (Asparagus officinalis) $(8,13,27)$; and foliar diseases of alfalfa $(28,29,44)$ and soybean (9). S. vesicarium also causes a stem and root rot on radish sprouts (4) and brown spot of European pear ( $P$. communis) leaves and fruit $(22,31)$.

The parsley $S$. vesicarium isolates caused similar leaf spots when inoculated onto carrot and celery. Therefore, this pathogen is not host specific to parsley but can infect other plants in the Apiaceae family. However, the host ranges and possible host specificities of $S$. vesicarium pathogens from various crops remain unclear due to differing reports. Some previous reports indicate that $S$. vesicarium can infect a broad range of plants, with onion developing typical purple blotch symptoms when inoculated with an asparagus isolate (43) and asparagus, garlic, and onion each being susceptible to $S$. vesicarium isolates from all three of these plants (3). However, a different isolate of $S$. vesicarium from onion failed to infect asparagus (13). Kohl et al. (22) found that asparagus and onion isolates did not infect pear leaves or fruit. In this study, parsley isolates of $S$. vesicarium did not infect onion when inoculated under controlled conditions. Additional studies using larger numbers of isolates from various hosts would be needed to further address the question of cross-pathogenicity of $S$. vesicarium pathogens.

Using a freeze-blotter seed assay and inoculations onto parsley, we confirmed that pathogenic isolates of $S$. vesicarium were seedborne on parsley at an incidence of $0.25 \%$. Three of four isolates from seed caused leaf spot symptoms when inoculated onto parsley plants. Seedborne S. vesicarium has been reported for alfalfa (29), onion $(1,35)$, and radish (4). Therefore, one possible inoculum source for this disease appears to be parsley seed. Although the incidence of infested parsley seed was low, such an infestation rate could be significant for the farmer. For typical parsley production in California, the seeding rate is approximately $17 \mathrm{~kg} / \mathrm{ha}$ or 4.41 million seed/ha. Given the $0.25 \%$ infestation rate, potentially there could be 18,750 infested seed/ha. Because all parsley is irrigated with overhead sprinkler systems, this low level of infested seed could result in significant disease due to a favorable environment consisting of high-density plantings and splashing irrigation water.

If freeze-blotter assays for detecting $S$. vesicarium on parsley seed were to be used commercially, seed and lab technicians would need to exercise caution in examining the seed. The Alternaria spp. found on parsley seed should be readily recognized morpho-

Table 1. Dimensions of conidia and conidiophores of Stemphylium vesicarium isolates from parsley

\begin{tabular}{|c|c|c|c|}
\hline \multirow[b]{2}{*}{ Structure $^{\mathrm{a}}$} & \multicolumn{2}{|c|}{ Isolate measurements } & \multirow[b]{2}{*}{ Means for two isolates } \\
\hline & 09-14B1 & 09-18B2 & \\
\hline \multicolumn{4}{|l|}{ Conidia } \\
\hline \multicolumn{4}{|c|}{ Length $(\mu \mathrm{m})$} \\
\hline Range & $(18.4-) 19.9-28.0(-41.3)$ & $(16.4-) 22.3-33.5(-41.1)$ & 25.9 \\
\hline SD & 4.4 & 5.6 & $\ldots$ \\
\hline \multicolumn{4}{|c|}{ Width $(\mu \mathrm{m})$} \\
\hline Range & $(10.9-) 13.0-16.4(-18.5)$ & $(10.3-) 13.8-18.2(-23.2)$ & 15.4 \\
\hline SD & 1.7 & 2.2 & $\ldots$ \\
\hline \multicolumn{4}{|c|}{ Length/width ratio } \\
\hline Range & $1.2-2.2$ & $1.2-2.4$ & $\ldots$ \\
\hline Mean & 1.7 & 1.8 & 1.8 \\
\hline \multicolumn{4}{|c|}{ Conidiophores } \\
\hline \multicolumn{4}{|c|}{ Width $(\mu \mathrm{m})$} \\
\hline Range & $5.5-8.3$ & $5.5-8.3$ & 6.9 \\
\hline SD & 0.5 & 0.6 & $\ldots$ \\
\hline \multicolumn{4}{|c|}{ Apical cell width $(\mu \mathrm{m})$} \\
\hline Range & $8.3-11.1$ & $8.3-11.1$ & 9.7 \\
\hline $\mathrm{SD}$ & 0.8 & 0.9 & $\ldots$ \\
\hline
\end{tabular}

${ }^{\text {a }}$ Fungal structures were taken from 4-week-old cultures on V8 juice agar plates that were incubated in light on a cycle of $12 \mathrm{~h}$ of light and $12 \mathrm{~h}$ of darkness at $22^{\circ} \mathrm{C}$. For each isolate, 50 spores and 20 conidiophores were measured. $\mathrm{SD}=$ standard deviation. 
logically due to the beaked conidia that are borne in chains. However, when examining seed with a dissecting microscope, Ulocladium spp. appear very similar morphologically to Stemphylium; therefore, caution is required in differentiating these two genera (45). In addition, because previous studies indicate that $S$. botryosum can be present as a contaminant on parsley seed, the seed technician will need to differentiate between the pathogenic $S$. vesicarium that causes leaf spot and $S$. botryosum that is not known to cause a foliar disease on parsley. Such a differentiation based on morphology will necessitate examining spores using glass-slideprepared specimens and a compound microscope.

A thorough examination of the epidemiology of this disease is beyond the scope of this report. However, it is interesting to note that some epidemiological aspects of Stemphylium diseases of asparagus, garlic, and pear may also pertain to parsley. For these other diseases, inoculum is associated with senescing and dead host tissues and debris. Pseudothecia of the Pleospora herbarum perfect stage develop on senescent and dead asparagus fern debris and are a key inoculum source for purple spot $(12,13,18,21)$. $P$. allii pseudothecia also are prevalent on crop residues, senescent leaves, and old flower stalks of garlic $(13,38)$. Pear leaf litter and senescent leaves of orchard floor cover crop species support the development of both $P$. allii pseudothecia and $S$. vesicarium conidia $(31,41,42)$.

In California, although parsley is grown as an annual crop, each planting is harvested multiple times. Each time a flush of growth is cut and harvested, many loose leaves and stem pieces remain in the field and become embedded in the parsley crowns. The cut ends of stems still attached to the plant crowns dry out and die. Such detached parsley debris and senescing cut stem ends could function as substrates for either the conidial or possibly the pseudothecial stage of this foliar pathogen. Also, after cutting and removing a flush of foliage, the older, lower leaves remain attached to the plant; these older leaves were often found to have leaf spots. Infection of subsequent regrowth in the field suggests that in-field inoculum is coming from the crop debris or remaining diseased foliage. Splashing water from overhead sprinkler irrigation would provide the means and environment for subsequent inoculum dispersal, infection, and disease development. The nature of this inoculum (conidia versus ascospores) is not known for parsley. Future studies could examine such field situations for the presence of pseudothecia or conidia of this pathogen.

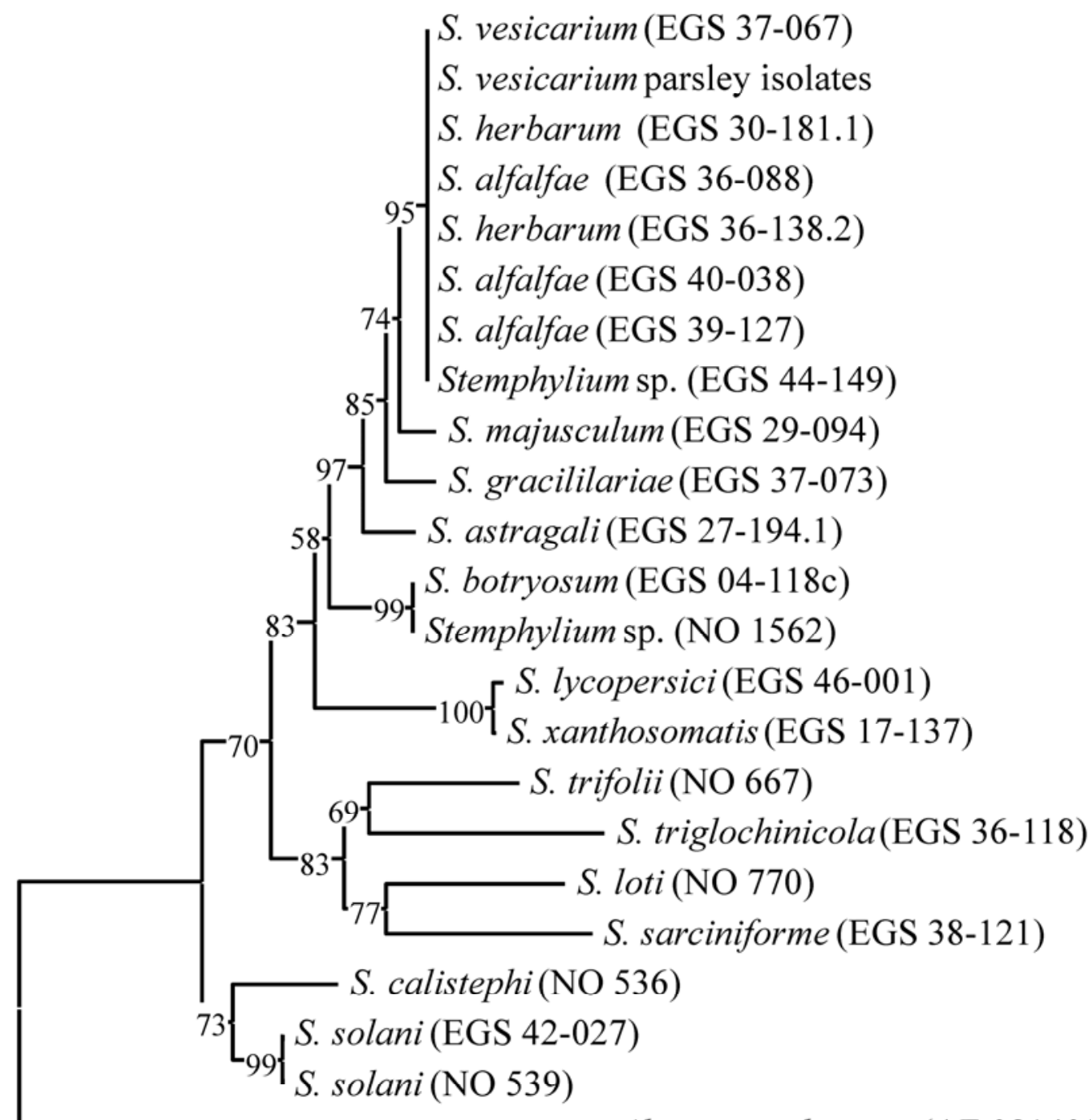

Alternaria alternata(AF 081400)

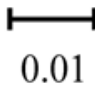

Fig. 3. Jukes-Cantor distance tree generated using the neighbor-joining method for the aligned partial DNA sequences of glyceraldehyde-3-phosphate dehydrogenase. The analysis was done using the software MEGA version 4.0 (48) using an alignment length of 562 bp. Numbers at the branch nodes indicate the confidence values obtained from bootstrap analysis using 2,000 permutations of the data set. 
Although Septoria late blight is typically the most destructive disease of parsley in California, the addition of Stemphylium leaf spot adds yet another challenge that California growers must deal with while producing large volumes of high-quality, defect-free parsley. Information is lacking regarding which fungicides might be effective for controlling $S$. vesicarium on parsley. Field studies involving other crops have demonstrated that chlorothalonil, procymidone, and tebuconazole can manage Stemphylium spp. in asparagus, garlic, or onion $(2,14,17)$; thiram is used to control Stemphylium spp. on pear (33). None of these fungicides, however, is registered for use on parsley in California. The cultivar experiment indicates that at least one flat leaf parsley cultivar might be resistant; therefore, a search for other resistant parsley cultivars could assist growers. Curly leaf cultivars consistently developed less severe symptoms than flat leaf varieties.

Stemphylium leaf spot is not the only new foliar problem of parsley that has been recently documented in California. A new bacterial leaf spot disease caused by two different pathovars of Pseudomonas syringae (pvs. apii and coriandricola) was found in commercial fields (5). Therefore, growers and field personnel must distinguish between four foliar diseases of parsley (23) (Table 4). Powdery mildew can easily be identified because of the typical white, powdery, superficial mycelium and sporulation on leaves. Septoria late blight is distinctive because of the obvious brown to black pycnidia that form in most of the angular leaf spots; however, early stages of late blight will not have pycnidia present in leaf spots and, therefore, could be mistaken for bacterial leaf spot. Bacterial leaf spot causes angular, tan to brown leaf spots that lack any mycelial or fungal structures. Stemphylium leaf spot also lacks fungal structures in the spots but is characterized by oval to round spots that often contain concentric rings of light and dark tissues.

\section{Acknowledgments}

We thank P. Elia (United States Department of Agriculture-Agricultural Research Service, Beltsville, MD) and P. Ayala and K. Kammeijer (University of California Cooperative Extension, Salinas) for assisting with this study; the

Table 3. Stemphylium and other dematiaceous fungi observed on parsley seed following a freeze-blotter seed assay

\begin{tabular}{lccc}
\hline & \multicolumn{3}{c}{$\begin{array}{c}\text { Number of seed colonized by a } \\
\text { dematiaceous species/400 total tested }\end{array}$} \\
\cline { 2 - 4 } Exp. $^{\mathbf{b}}$ & Stemphylium & Ulocladium & Alternaria $^{\mathbf{a}}$ \\
\hline 1 & 0 & 3 & 3 \\
2 & 1 & 3 & 26 \\
3 & 1 & 3 & 14 \\
4 & 2 & 1 & 3 \\
Mean & 1 & 2.5 & 11.5 \\
Seedborne $(\%)$ & 0.25 & 0.63 & 2.9 \\
\hline
\end{tabular}

${ }^{a}$ For each experiment, the seed assay was completed using 100 seeds in each of four replications. Final counts are based on seed examined at the 10-day period. The experiment was conducted four times.

${ }^{\mathrm{b}}$ Experiment number. Mean $=$ mean number/experiment.

Table 2. Pathogenicity of Stemphylium vesicarium isolates from parsley to parsley cultivars and other commercial crops

\begin{tabular}{|c|c|c|c|c|c|}
\hline \multirow[b]{2}{*}{ Plant, cultivar b } & \multicolumn{5}{|c|}{ Stemphylium isolates and control (first test/second test) ${ }^{\mathbf{a}}$} \\
\hline & 09-12B1 & 09-13B1 & 09-14B1 & 09-15B1 & Water \\
\hline \multicolumn{6}{|l|}{ Parsley cultivars } \\
\hline \multicolumn{6}{|l|}{ Parsley, flat leaf } \\
\hline 'Dark Green Italian' & $++/++$ & $++/++$ & $++/++$ & $++/++$ & $-1-$ \\
\hline 'Forest Green' & $++/+$ & $++/++$ & $++/+$ & $++/+$ & $-1-$ \\
\hline 'Italian Flat Leaf' & $++/++$ & $++/++$ & $++/++$ & $++/++$ & $-1-$ \\
\hline 'Rialto' & $+/+$ & $++/+$ & $++/+$ & $++/+$ & $-1-$ \\
\hline ‘Titan’ & $++/+$ & $++/+$ & $+/++$ & $++/+$ & $-1-$ \\
\hline \multicolumn{6}{|l|}{ Parsley, curly } \\
\hline 'Dark Moss Curled' & $+/+$ & $+/+$ & $+/+$ & $+/+$ & $-1-$ \\
\hline 'Evergreen' & $+/+$ & $+/+$ & $+/+$ & $+/+$ & $-1-$ \\
\hline 'Jade' & $+/+$ & $+1-$ & $+/+$ & $+/+$ & $-1-$ \\
\hline 'Krausa' & $+/-$ & $+/+$ & $+/+$ & $+/+$ & $-1-$ \\
\hline 'Moss Curled' & $+/-$ & $+/+$ & $+/+$ & $+/+$ & $-1-$ \\
\hline 'Triple Curled' & $-1-$ & $-1+$ & $+/-$ & $-1-$ & $-1-$ \\
\hline \multicolumn{6}{|l|}{ Other crops } \\
\hline \multicolumn{6}{|l|}{ Carrot } \\
\hline 'Scarlet Nantes' & $+/+$ & $+/+$ & $+/-$ & $+/+$ & $-1-$ \\
\hline 'Tendersweet' & $+/+$ & $+/+$ & $+/+$ & $+/+$ & $-1-$ \\
\hline Celery, 'Conquistador' & $+/+$ & $+/+$ & $+/+$ & $+/-$ & $-1-$ \\
\hline Leek, 'Lancelot' & $-1-$ & $-1-$ & $-1-$ & $-1-$ & $-1-$ \\
\hline Onion, 'California red' & $-1-$ & $-1-$ & $-1-$ & $-1-$ & $-1-$ \\
\hline \multicolumn{6}{|l|}{ Spinach } \\
\hline 'Bolero’ & $-1-$ & $-1-$ & $-1-$ & $-1-$ & $-1-$ \\
\hline 'Lasio’' & $-1-$ & $-1-$ & $-1-$ & $-1-$ & $-1-$ \\
\hline Tomato, 'Champagne' & $-1-$ & $-1-$ & $-1-$ & $-1-$ & $-1-$ \\
\hline \multicolumn{6}{|l|}{ Pear fruit, unripe $\mathrm{c}^{\mathrm{c}}$} \\
\hline Unwounded & $-1-$ & $-1-$ & $-1-$ & $-1-$ & $-1-$ \\
\hline Wounded & $+/+$ & $+/+$ & $+/+$ & $+/+$ & $-1-$ \\
\hline \multicolumn{6}{|l|}{ Pear fruit, ripe ${ }^{c}$} \\
\hline Unwounded & $-1-$ & $-1-$ & $-1-$ & $-1-$ & $-1-$ \\
\hline Wounded & $+/+$ & $+/+$ & $+/+$ & $+/+$ & $-1-$ \\
\hline Positive control $^{\mathrm{d}}$ & $+/++$ & $+/+$ & $++/+$ & $++/+$ & $-1-$ \\
\hline
\end{tabular}

${ }^{\text {a }}$ For plants, 10 leaves per cultivar were evaluated for the development of leaf spots at 24 days post inoculation using the following scale: $-=$ no leaf spots; $+=$ minor leaf spots (spot size $<5 \mathrm{~mm}$ in diameter) $++=$ moderate leaf spots (spot size $\geq 5$ mm in diameter). For pear fruit, results were evaluated for the development of lesions for up to 10 days post inoculation using the following scale: $-=$ no lesions and $+=$ lesions present.

b All plants had 6 to 10 true leaves when spray inoculated with conidial suspensions $\left(10^{5}\right.$ conidia/ml). Controls were treated with sterile distilled water plus Tween 20. Plants were placed in clear plastic bags for $48 \mathrm{~h}$, unbagged, then maintained in a greenhouse (20 to $\left.24^{\circ} \mathrm{C}\right)$. Results from the two pathogenicity tests are presented as first test/second test.

c Pear fruit ('Bartlett') were inoculated with the same conidial suspensions. Both green unripe and yellow ripe fruit were used and inoculum was placed on both unwounded and wounded spots. Controls were treated with sterile distilled water plus Tween 20. Pear fruit were placed in an enclosed humid chamber (lidded plastic box) at $22^{\circ} \mathrm{C}$ for $48 \mathrm{~h}$ and later incubated in a dry plastic box in the open air at room temperature. Results from the two pathogenicity tests are presented as first test/second test.

${ }^{\mathrm{d}}$ Control was Dark Green Italian flat leaf parsley. 


\begin{tabular}{|c|c|c|c|c|}
\hline \multirow[b]{2}{*}{ Disease, pathogen } & \multicolumn{4}{|c|}{ Symptoms and signs } \\
\hline & $\begin{array}{c}\text { Tan to brown } \\
\text { leaf spots }\end{array}$ & $\begin{array}{l}\text { Leaf spots } \\
\text { circular, oval }\end{array}$ & $\begin{array}{c}\text { Dark brown to black } \\
\text { fungal structures }\end{array}$ & $\begin{array}{l}\text { Mycelial growth on } \\
\text { leaf surface }\end{array}$ \\
\hline Septoria late blight, Septoria petroselini & Yes & No (usually angular) & Yes (pycnidia) & No \\
\hline Stemphylium leaf spot, Stemphylium vesicarium & Yes & Yes & No & Yes (sparse) \\
\hline Powdery mildew, Erysiphe orontii & No & No & No & Yes (profuse, white) \\
\hline Bacterial leaf spot, Pseudomonas syringae & Yes & No (always angular) & No & No \\
\hline
\end{tabular}

White Seed Company (Oxnard, CA) for providing seed and information; M. McGrath for reviewing the manuscript; and M. Poe for assisting with the figures.

\section{Literature Cited}

1. Aveling, T. A. S., Snyman, H. G., and Naude, S. P. 1993. Evaluation of seed treatments for reducing Alternaria porri and Stemphylium vesicarium on onion seed. Plant Dis. 77:1009-1011.

2. Basallote-Ureba, M. J., Prados-Ligero, A. M., and Melero-Vara, J. M. 1998. Effectiveness of tebuconazole and procymidone in the control of Stemphylium leaf spots in garlic. Crop Prot. 17:491-495.

3. Basallote-Ureba, M. J., Prados-Ligero, A. M., and Melero-Vara, J. M. 1999. Aetiology of leaf spot of garlic and onion caused by Stemphylium vesicarium in Spain. Plant Pathol. 48:139-145.

4. Belisario, A., Vitale, S., Luongo, L., Nardi, S., Talevi, S., and Corvi, F. 2008. First report of Stemphylium vesicarium as causal agent of wilting and root rotting of radish sprouts in Italy. Plant Dis. 92:651.

5. Bull, C. T., Clarke, C. R., Cai, R., Vinatzer, B. A., Jardini, T. M., and Koike, S. T. 2011. Multilocus sequence typing of Pseudomonas syringae sensu lato confirms previously described genomospecies and permits rapid identification of $P$. syringae pv. coriandricola and $P$. syringae pv. apii causing bacterial leaf spot on parsley. Phytopathology 101:847-858.

6. California Agricultural Statistics Service. 2010. County Agricultural Commissioners' Data. California Department of Food and Agriculture, Sacramento, CA.

7. Camara, M. P. S., O’Neill, N. R., and van Berkum, P. 2002. Phylogeny of Stemphylium spp. based on ITS and glyceraldehyde-3-phosphate dehydrogenase gene sequences. Mycologia 94:660-672.

8. Cunnington, J. H., and Irvine, G. 2005. Purple spot of asparagus caused by Stemphylium vesicarium in Victoria. Australas. Plant Pathol. 34:421-422.

9. Darrag, I. E., Zayed, M. A., El-Mosallamy, H. M., and El-Gantiry, S. M. 1982. Studies on Stemphylium leaf spot of soybean in Egypt. Agric. Res. Rev. 60:93-103.

10. du Toit, L. J., and Derie, M. L. 2008. Freeze-blotter spinach seed health assay protocol for Stemphylium botryosum, Cladosporium variabile, and Verticillium dahliae. In: Lab Protocol for the Vegetable Seed Pathology Program at Washington State University. Mt. Vernon NWREC, Mt. Vernon, WA.

11. du Toit, L. J., Derie, M. L., and Hernandez-Perez, P. 2005. Verticillium wilt in spinach seed production. Plant Dis. 89:4-11.

12. Evans, T. A., and Stephens, C. T. 1984. First report in Michigan of the teleomorph of Stemphylium vesicarium, causal agent of purple spot of asparagus. Plant Dis. 68:1099.

13. Falloon, P. G., Falloon, L. M., and Grogan, R. G. 1987. Etiology and epidemiology of Stemphylium leaf spot and purple spot of asparagus in California. Phytopathology 77:407-413.

14. Fantino, M. G., Ponti, I., Stefanell, D., and Baldazzi, D. 1991. Indagini di laboratorio e di campo per la difesa dell'asparago dalla brusciatura estiva. Inf. Fitopatol. 12:37-42.

15. Farr, D. F., Rossman, A. Y., Palm, M. E., and McCray, E. B. Fungal Databases, Systematic Botany and Mycology Laboratory. U.S. Dep. Agric. Agric. Res. Serv. http://nt.ars-grin.gov/fungaldatabases/

16. Ginns, J. H. 1986. Compendium of plant disease and decay fungi in Canada 1960-1980. Res. Br. Can. Agric. Publ. 1813:416.

17. Grinstein, A., Frankel, H., Austerweil, M., and Kritzman, G. 1988. Airassisted placement spraying for Stemphylium control in seed onions. Crop Prot. 7:356-360.

18. Hausbeck, M. K., Hartwell, J., and Byrne, J. M. 1999. Epidemiology of Stemphylium leaf spot and purple spot in no-till asparagus. Acta Hortic. 479:201-209.

19. Hernandez-Perez, P., and du Toit, L. J. 2006. Seedborne Cladosporium variabile and Stemphylium botryosum in spinach. Plant Dis. 90:137-145.

20. Inderbitzin, P., Mehta, Y. R., and Berbee, M. L. 2009. Pleospora species with Stemphylium anamorphs: a four locus phylogeny resolves new lineages yet does not distinguish among species in the Pleospora herbarum clade. Mycologia 101:329-339.

21. Johnson, D. A. 1990. Effect of crop debris management on severity of Stemphylium purple spot of asparagus. Plant Dis. 74:413-415.

22. Kohl, J., Groenenboom-de Haas, B., Goossen-van de Geijn, H., Speksnijder, A., Kastelein, P., de Hoog, S., and Gerrits van den Ende, B. 2009. Pathogenicity of Stemphylium vesicarium from different hosts causing brown spot in pear. Eur. J. Plant Pathol. 124:151-162

23. Koike, S. T., Gladders, P., and Paulus, A. O. 2007. Vegetable Diseases: A Color Handbook. Manson Publishing Ltd., London.

24. Koike, S. T., Gonzales, T. G., Henderson, D. M., and Oakes, E. D. 1997. Evaluation of fungicides for control of Septoria blight of parsley, 1996 Fungic. Nematicide Tests 52:101.

25. Koike, S. T., Liu, H.-Y., Sears, J., Tian, T., Daugovish, O., and Dara, S. 2012. Distribution, cultivar susceptibility, and epidemiology of Apium virus $Y$ on celery in coastal California. Plant Dis. 96:612-617.

26. Koike, S. T., and Saenz, G. S. 1994. Occurrence of powdery mildew on parsley in California. Plant Dis. 78:1219.

27. Lacy, M. L. 1982. Purple spot: a new disease of young asparagus spears caused by Stemphylium vesicarium. Plant Dis. 66:1198-1200.

28. Lamprecht, S. C., Baxter, A., and Thompson, A. H. 1984. Stemphylium vesicarium on Medicago spp. in South Africa. Phytophylactica 16:73-75.

29. Lamprecht, S. C., and Knox-Davies, P. S. 1984. Stemphylium vesicarium on lucerne (Medicago sativa) seeds in South Africa. Phytophylactica 16:189193.

30. Lewis, G. D. 1962. Stemphylium leaf spot of parsley. (Abstr.). Phytopathology $52: 925$

31. Llorente, I., and Montesinos, E. 2006. Brown spot of pear: an emerging disease of economic importance in Europe. Plant Dis. 90:1368-1375.

32. Miller, S. A., Colburn, G. C., and Evans W. B. 1999. Management of Septoria leaf blight of parsley with fungicides and efficacy of a disease predictive model. (Abstr.). Phytopathology 89:S53.

33. Montesinos, E., and Vilardell, P. 1992. Evaluations of FAST as a forecasting system for scheduling fungicide sprays for control of Stemphylium vesicarium on pear. Plant Dis. 76:1221-1226.

34. Nawrocki, J. 2005. Susceptibility of different parsley cultivars to infestation by pathogenic fungi. Acta Agrobot. 58:163-169.

35. Neergaard, P. 1977. Seed Pathology. Macmillan Press, London.

36. Nowicki, B. 1997. Occurrence of root parsley pathogens inhabiting seeds. Acta Agrobot. 50:27-34

37. Nowicki, B. 1997. Etiology of root parsley damping-off. Acta Agrobot 50:35-40

38. Prados-Ligero, A. M., Gonzalez-Andujar, J. L., Melero-Vara, J. M., and Basallote-Ureba, M. J. 1998. Development of Pleospora allii on garlic debris infected by Stemphylium vesicarium. Eur. J. Plant Pathol. 104:861-870.

39. Prados-Ligero, A. M., Melero-Vara, J. M., Corpas-Hervias, C., and Basallote-Ureba, M. J. 2003. Relationships between weather variables, airborne spore concentrations and severity of leaf blight of garlic caused by Stemphylium vesicarium in Spain. Eur. J. Plant Pathol. 109:301-310.

40. Rao, N. N. R., and Pavgi, M. S. 1975. Stemphylium leaf blight of onion. Mycopathologia 56:113-118.

41. Rossi, V., Pattori, E., and Bugiani, R. 2008. Sources and seasonal dynamics of inoculum for brown spot disease of pear. Eur. J. Plant Pathol. 121:147159.

42. Rossi, V., Pattori, E., Giosue, S., and Bugiani, R. 2005. Growth and sporulation of Stemphylium vesicarium, the causal agent of brown spot disease of pear, on herb plants of orchard lawns. Eur. J. Plant Pathol. 111:361-370.

43. Shishkoff, N., and Lorbeer, J. W. 1989. Etiology of Stemphylium leaf blight of onion. Phytopathology 79:301-304.

44. Shivas, R. G.1989. Fungal and bacterial diseases of plants in Western Australia. J. R. Soc. West. Aust. 72:1-62.

45. Simmons, E. G. 1967. Typification of Alternaria, Stemphylium, and Ulocladium. Mycologia 59:67-92

46. Simmons, E. G. 1969. Perfect states of Stemphylium. Mycologia 61:1-26.

47. Suheri, H., and Price, T. V. 2001. Purple leaf blotch disease of Allium spp. in Australia. Acta Hortic. 555:171-173.

48. Tamura, K., Dudley, J., Nei, M., and Kumar, S. 2007. MEGA4: Molecular Evolutionary Genetics Analysis (MEGA) software version 4.0. Mol. Biol. Evol. 24:1596-1599.

49. Tian, T., Liu, H.-Y., and Koike, S. T. 2008. First report of Apium virus $Y$ on cilantro, celery, and parsley in California. Plant Dis. 92:1254.

50. USDA. 2010. National Agricultural Statistics Service. US Vegetable Commodity Rankings. www.agcensus.usda.gov/Publications/2007/Full_Report/ CenV1US1.txt

51. Van Berkum, P., Beyene, D., and Eardly, B. D. 1996. Phylogenetic relationships among Rhizobium species nodulating the common bean (Phaseolus vulgaris L.). Int. J. Syst. Bacteriol. 46:240-244. 